\title{
A timely update to an important anthology of Afrikaans poems in translation
}

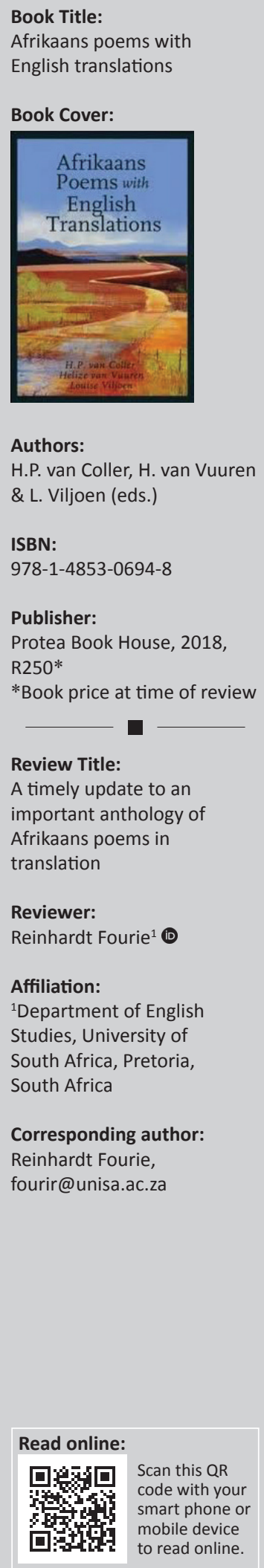

Afrikaans poems with English translations (2018) is an updated edition of an anthology by the same title, originally edited by A.P. Grové and C.J.D. Harvey and published in 1962 by Oxford University Press. While fairly similar to the latter edition in terms of the number of poems included in the collection, the range of poets featured in Protea Book House's updated and expanded edition is far more varied and diverse.

In their editors' note, H.P. van Coller, Helize van Vuuren and Louise Viljoen call the volume an attempt 'to collate the best and at the same time the most representative poems' in Afrikaans (n.p.). Such a task is understandably difficult and fraught with unfortunate trade-offs and sacrifices. Indeed, even though the editors were aiming to limit themselves to including only 'a hundred of the most important poems in Afrikaans', they ultimately ended slightly over that with 113. The poems included range from work by the likes of earlier writers such as Eugène N. Marais, C. Louis Leipoldt, N.P. van Wyk Louw, Elisabeth Eybers, D.J. Opperman, S.V. Petersen, Peter Blum, Ingrid Jonker and Adam Small, to more recent work by Antjie Krog, Marlene van Niekerk, Joan Hambidge, Diana Ferrus, Loftus Marais, Ronelda S. Kamfer, Nathan Trantraal and many besides and between.

For the English reader who does not feel comfortable enough with their own level of Afrikaans to approach its poetry in the original language, this anthology offers a welcome format: every poem appears in the original Afrikaans and in English translation. This presents the reader with an opportunity to still read and enjoy the sound and feel of the poem in Afrikaans, while at the same time benefitting from the availability of the translation. This might enable readers less familiar with Afrikaans poetry to enjoy the originals on their own terms, while at the same time allowing for the reading of new depth into these Afrikaans poems based on the interpretations that are the English translations.

Some of the translations by the likes of Guy Butler and C.J.D. Harvey have been carried over from the 1962 edition. Others, especially of poems that have appeared since, originate from other publications and websites. Additionally, some new translations were undertaken specifically for this anthology. This results, for instance, in the inclusion of a co-authored translation of Ingrid Jonker's famous 'Die kind wat doodgeskiet is deur soldate by Nyanga' (pp. 180-181) by her contemporaries Jack Cope and William Plomer, as well as a translation of her poem 'Ontvlugting' (pp. 176-177) by André Brink and Antjie Krog. This certainly speaks to how the work of certain older Afrikaans poets has endured, both influencing and fascinating those generations that have followed.

The translations, old and new, were evaluated by the editors both in terms of their 'respect for the source text' and their quality 'as poems in their own right' (n.p.). The approaches to the translations do therefore vary from translator to translator, but this is certainly not in any way to the detriment of the collection. In fact, it serves to neatly underscore the increasingly varied nature of Afrikaans poetry and its reception.

For example, 'Winter's night' (p. 13), Guy Butler's translation of Marais's 'Winternag' (p. 12) that also appeared in the 1962 edition, is faithful in its effective expression of the sombreness that characterises the original poem. What remains for me an important part of this lies in Butler achieving a comparable rhyme scheme and rhythm. For example, the second stanza's opening, 'O treurig die wysie/ op die ooswind se maat, / soos die lied van 'n meisie / in haar liefde verlaat' becomes 'O tune grief-laden / on the east wind's pulse / like the song of a maiden /

How to cite this book review: Fourie, R., 2019, 'A timely update to an important anthology of Afrikaans poems in translation', Literator 40(1), a1622. https://doi.org/10.4102/lit.v40i1.1622

Copyright: ( 2019. The Authors. Licensee: AOSIS. This work is licensed under the Creative Commons Attribution License. 
whose lover proves false'. Andries Wessels's beautiful translation of Boerneef's 'Die berggans het ' $n$ veer laat val' (pp. 170-171) also retains the rhyme scheme - and therefore romantic lyricism - of the original:

\author{
A lone goose dropped a feather light \\ A lone goose dropped a feather light \\ from the cliffs at Wupperthal's highest height \\ my heart extends yet more and more \\ I send thee the feather for \\ with this my dear I wish to say \\ how deep my love for thee will stay
}

Quite delightfully, one is treated in certain cases to more than one translation of the same poem. Ernst van Heerden's short 'Die gewigopteller' (pp. 130-131) has a translation by the poet himself in addition to a translation by C.J.D. Harvey, while translations of Ina Rousseau's 'Eden' (p. 154) are complemented by separate translations by Harvey (p. 155) and J.M. Coetzee (p. 157) - the former favouring an attempt to honour the source text in form, and the latter taking more liberty with the form, but in so doing is no less true to the spirit of the poem.

Surely, not all readers will find all the translations in Afrikaans poems with English translations equally convincing. For me, Leon de Kock's translation of a poem by Ronelda S. Kamfer and Mike Dickman's translation of a poem by Nathan Trantraal are less compelling than the source texts, but the work of these poets does offer particular challenges to translators (especially Trantraal's poem that is included in the collection being in Kaaps) and so the attempt to make these poems available to English readers must therefore still be acknowledged and appreciated.

The publication of a text such as Afrikaans poems with English translations should be welcomed and lauded. I hope that the availability of these poems in English will spark further interest in Afrikaans poetry and lead to more translations and even comparative studies. Perhaps, through a text such as this, which offers a timeously updated corpus of translations of not only older works but of some of the most exciting poetry that has appeared in Afrikaans since the 1980s up to the present, Afrikaans poetry in translation might find its way into the literature curricula and research foci of English literature scholars around the world. If not that, then this collection certainly still offers an enjoyable journey through Afrikaans poetry over the course of about a century.

\section{Reference}

Grové, A.P. \& Harvey, C.J.D. (eds.), 1962, Afrikaans poems with English translations, Oxford University Press, Cape Town. 